\title{
A CONTRIBUTION TO THE INTERPRETATION OF THE DISPUTE OVER METHOD IN SOCIAL SCIENCES
}

\author{
UDC 303.01
}

\author{
Nina Pavlović \\ University of Niš, Faculty of Philosophy, Department of Sociology, Serbia
}

\begin{abstract}
In this article we analyze the basic theoretical assumptions of participants in the Methodenstreit dispute. The opposing views of positivists and historists have been analyzed according to the key positivist rules set out by Kolakowski (1972): phenomenalism, nominalism, status of value judgements and unity of science. In particular, the main consequences of different understandings of the relationship between the methods of the natural and social sciences were discussed: a) understanding of the goal of the social sciences: comprehension and explanation, $b$ ) the possibility of discovering universal laws as opposed to contextual analysis of unique phenomena; c) the place of social sciences in the system of sciences. We point to the efforts of the representatives of both directions to affirm the knowledge possibilities of the social sciences, but with different perceptions of the direction of the development of the social sciences - towards conquering the external or internal world.
\end{abstract}

Key words: Methodenstreit, positivism, historicism, social science method.

\section{INTRODUCTION}

The dispute over method (Methodenstreit) marks a debate within which the methodological settings of positivism is questioned, with the affirmation of an alternative view of the social science method within historicism. Conflicts of these two directions emerged in the nineteenth century, first in the field of economics, through discussions in the works of Carl Menger and Gustav von Schmoller ${ }^{1}$, and then the dispute over method spread to

Received Marth 12, 2020 / Accepted May 21, 2020

Corresponding author: Nina Pavlović

University of Niš, Faculty of Philosophy, Ćirila i Metodija 2, 18000 Niš, Serbia

E-mail: nina.pavlovic@ filfak.ni.ac.rs

${ }^{1}$ In economics, this dispute begins with the opposition of the German History School and the Austrian School. Members of the older German history school (Roscher, Knies) seek to supplement the classical economy method by incorporating historical analysis and a multidisciplinary approach, while the representatives of the younger history school reject the possibility of discovering economic laws by a deductive method, advocating a descriptive-historical method and expanding the subject of economics to the study of social-historical context; 
other social sciences. The demarcation of the thinkers' affiliation in any direction is always faced with difficulties and relative arbitrariness, since one can rarely speak of the presence of a specific philosophy in 'pure' form in the works and theories of thinkers; there are always antecedents of one direction, as well as new generations of a directions that emerge from it, modifying the basic ideas (Kolakovski 1972). In this paper we will discuss the ideas of the initiator of the dispute, Carl Menger and Gustav Schmoller; representatives of positivism Auguste Comte; representatives of historism in economics - Wilhelm Roscher and Karl Knies, and in history: Wilhelm Dilthey who analyses the position and characteristics of the spiritual sciences (Geisteswissenchaften), which includes history; Wilhelm Windelband and Heinrich Rickert - also representing the ideas of historism but applying different arguments, approaching the problem from the perspective of the logic of interests of the natural and social sciences.

As Samuel Bostaph states, there are three points of view on the significance of this dispute: a) authors who consider the method dispute to be a futile debate, such as Joseph Schumpeter who states that the interests of the conflicting parties are so different that it is pointless to expect their agreement on methods; b) authors who are indifferent to the dispute; and c) authors who consider this to be a fruitful debate that has led to a re-examination of relevant topics (Bostaph 1978, 6). Bostaph believes that the understanding which prevails is one of complementarity of both methods in economics, their applicability to different subjects and for the achievement of different scientific goals. For the study of some phenomena the abstract-deductive method is suitable, and for the study of others the historical method; this difference in methods can be simplified by contrasting the deductive and inductive method (Bostaph 1978, 8). This concept is consistent with Schmoller's interpretation that Menger's division of science into theoretical and historical can be reduced to a division into science with respect to the use of an inductive or deductive method (Agevall 1999, 67). However, Menger considered this interpretation a simplistic account of a problem involving disagreements about scientific goals (Stojanović 2008, 17). The subject of the method dispute is not reducible to the question of the appropriateness of the inductive or deductive method, but rather examines the epistemological foundations of the social sciences.

\section{FOUR RULES OF POSITIVISM}

Kolakowski defines positivism as "a collection of rules and evaluative criteria referring to human knowledge" (Kolakovski 1972, 31), that is, norms that determine what can be considered knowledge and what questions can reasonably be asked within science. The goal of positivism is to separate metaphysics from science, to distinguish between speculation and scientific knowledge that can be verified by empirical facts. Historism (Historismus) indicates the ideological and philosophical direction that occurred in Germany at the end of the nineteenth century, as well as a specific philosophical standpoint (Brdar 2008, 129): "as

Schmoller extends the subject of political economy to understanding the ethical principles that influence human actions, defining the viewpoint of an ethical school (Stojanović 2008, 17-19).

The founder of the Austrian school, Menger, formulates the division of economic sciences into theoretical, historical and practical ones, emphasizing the need to establish the exact laws and types of relations within a theoretical economy. There are disagreements within the Austrian school, especially regarding methodology, but the basic characteristics can be emphasized as: methodological individualism, methodological subjectivism, focus on processes of adaptation to change and exploration of conditions that maintain functioning of a spontaneous order (Stojanović 2008, 17-25). 
an outgrowth of Romanticism of the nineteenth century, historism rehabilitate sense of individuality of historical events, irreducible to the general, schematic structures" (Brdar 2008 , 137). Bostaph believes that the dispute over method actually expressed opposition to two conceptions of knowledge, that is, epistemological disagreement, although the participants in the dispute did not specifically emphasize it in their works (Bostaph 1978, 9). This is in agreement with Auguste Comte's principle that method cannot be considered outside the theoretical context; the more complex the phenomena, the more difficult and useless it is to separate the method from the theory (Comte 1989, 121).

Kolakowski (1972) distinguishes four qualities that express the basic characteristics of positivism: phenomenalism, nominalism, status of value judgements, unity of science.

A. According to phenomenalism (Kolakovski 1972, 31), phenomenon is inseparable from its essence; it is expressed in an experientially observable form, and any judgment that is not based on empirical evidence cannot be regarded as scientific. Positivism tends to sharply oppose and reject metaphysics: the basic goal is to free social sciences of arbitrariness and ambiguity, to ground the scientific method and characteristics of scientific knowledge in objective and verifiable sources of knowledge. As Comte point out, the positive spirit is first and foremost "realistic versus chimerical" (as cited in Fiamengo 1987, 118), and implies a focus on issues that are accessible to human reason and can therefore be resolved. Furthermore, a positive spirit means a contrast between the useful and the futile - the focus on studying problems that will lead to an improvement in the living conditions of society as a whole; the contrast of the certain and the unanswerable - the distinction between logically ordered systems of concepts and cognition versus the disorder of metaphysics; and finally, the contrast of the precise and the vague - the expression of the demand for the highest possible degree of precision, bearing in mind the character of the subject under study and the scientific goal, as opposed to arbitrary treatment of concepts and measures under the influence of metaphysical authorities.

From the point of view of historicism, society can only be fully examined if the categories of the spiritual world are studied side by side with the physical world: the essence of spiritual phenomena cannot be studied on the basis of their manifest dimensions. Individuals perceive all reality through internal experiences, individual forms of spiritual life that are accessible only to the individual who experiences them. The experiences of others are not directly recognizable, they can only be reached through interpretation on the basis of external signs, that is, understanding. From this notion it follows that the appearing dimensions do not capture the essence of spiritual phenomena, which can be completely internal and only indirectly accessible to the spiritual sciences (Geisteswissenchaften), through understanding.

B. Nominalism means the rejection of the existence of general phenomena outside of individual manifestations. Abstract sciences deal with the organization and systematization of experience, that is, they have no cognitive function in abstract, nonempirical realms of reality (Kolakovski 1972, 35). The aforementioned rule means the rejection of ideas such as "matter" and "spirit", which do not contribute to the scientific explanation but convey the discussion of specific scientific problems to the field of metaphysics. The aim is to ground scientific study in real-world phenomena as opposed to ideas that are subject to subjective and ambiguous interpretation; however, the rejection of general categories leads to a narrowing of social science subjects that can be considered too rigorous. According to Dilthey (1980), understanding and objectification enable the 
internal process of individual experiences to become external and general; through understanding (Verstehen), inner experiences receive meaning that is clear and accessible to study. The inner world shapes the way the natural world is experienced, creating the only reality that is available to us because: "[...] the reality, as it is, is possessed only in the facts of consciousness given to us in the inner experience" (Diltaj [Dilthey]1980, 46). For Dilthey, understanding is the knowledge of the interior based on external indicators, and the objectification of life implies the manifestation of the spirit in creations of relatively permanent character such as traffic, arrangement of trees in the park, from house placement to criminal conviction. The category of objective spirit, as Brdar points out, signifies "a concrete-historical whole that becomes the basic framework for understanding individual events" (Brdar 2008, 134). The aforementioned processes are precisely the manifestation of spiritual experience, opposing nominalism. In so doing, the subject of social sciences is not reduced to the impressions and experiences of the individual, but is situated in "objects which knowledge creates so that these impressions can be constructed" (Diltaj 1980, 126), that is, it includes abstractions that are created by the interpretation of internal spiritual phenomena.

C. In accordance with the foregoing characteristics, positivists reject the possibility of studying values, denying them their cognitive value. According to phenomenalism, studying values is rejected because values are concepts not given in empirical facts; according to nominalism, values are rejected as general entities that cannot be found in singular manifestations (Kolakovski 1972, 37). In contrast, the significance of values in historism can be viewed through three dimensions:

- Criterion for the choice of the subject of study: Rickert believes that social phenomena cannot be understood without considering their relation to values, which provide a motive for human actions (Milić 2014, 128). One object can only be learned by conceptualization; however, reality is irrational and cannot be reduced to concepts, so the result is a contrast between concept and reality (hiatus irrationalis), which can only be overcome through value. History is the science of unique events, which cannot be reduced to the cognitive concepts of the natural sciences, which further raises the problem of the criteria for choosing the subject of study. Rickert solves this problem by pointing out that the scientist must select topics that are universally relevant, and the significance of the topic can only be determined from the aspect of value (Agevall 1999, 137). Values themselves derive from culture, and historical sciences can be considered cultural sciences. Unique and unrepeatable events gain significance only in terms of value; understanding the value aspect enables interpretation of the meaning of the phenomenon (Oakes 1997, 67).

- The subject of teleological analysis: The significance of values in Schmoller's thought is reflected in the idea of using teleological analysis as a supplement to empirical analysis. Teleological examination of the phenomenon takes place in the categories of goal and means, as opposed to cause-and-effect analysis (Shionoya 2005 , 24). Schmoller advocates the possibility of factual study of values; rather than the normative approach, ethics is increasingly concerned with empirical analysis of existing values, thus approaching the science of society, sociology (as cited in Shionoya 2005, 23). In contrast to examining the particular values of political groups or classes, one must examine the universal values of a society, that is, values that are common to all members of a nation in one particular cultural age. 
- The epistemological and axiological basis of science (truth as value): Windelband resents the positivist notion of mixing logical and empirical settings; reality is divided into partial areas, subjects of empirical sciences, and the question of their epistemological foundations and validity remains unanswered. According to him, truth is value, and logic must be subordinated to axiology as a general theory of value (Oakes 1997, 64).

D. Methodological monism: Positivists advocate the unity of the natural and social science method, holding that the cognitive reach of the sciences is determined by the historical degree of their development; the social sciences are the last to develop as they study the phenomena that are most specific, most complex, and least self-contained (Comte 1989, 31). Social phenomena can be studied by relying on empirical facts, classifying all concepts not accessible to the senses into metaphysical concepts and studying the categories of the natural and social world in the same way. Historists, on the other hand, believe that social phenomena are specific because of the existence of unique intrinsic properties and experiences, and that their study requires fundamentally different methods from those of the natural sciences: experiencing, understanding, and objectification. The following section will look at the main implications of different views of the relationship between natural and social science method(s): a) defining the goal of the social sciences: understanding and explaining, b) the possibility of discovering universal laws as opposed to contextually analyzing unique phenomena; and c) the place of social sciences in the system of sciences.

\section{AIMS OF THE SOCIAL SCIENCES: EXPLANATION AND UNDERSTANDING}

It is precisely in the intrinsic properties of the spiritual categories that Dilthey sees the basis for the independence of the social sciences: while the goal of the natural sciences is explanation, the goal of the spiritual sciences is understanding. Understanding makes it possible to overcome the limitations of nomological knowledge through personal experiences; the mutual understanding of individuals enables togetherness. The task of the spiritual sciences is to discover the common characteristics of social phenomena, but in order to describe and analyze their individual forms of expression: "Communion, kinship, they appear to us in understanding, and this, on the other hand, allows us to perceive an infinite variety of differentiations, beginning with great differences between races, tribes, and people to the infinite diversity of individuals" (Diltaj 1980, 206, our translation). Schumpeter calls the historist's position "methodological collectivism" in order to express its focus on processes and institutions as collections of individuals and their interrelations (Bostaph 1978, 10). Understanding is reduced to understanding the relationships within the internal logic of phenomena to be able to cause them.

Given the notions of uniqueness of the phenomenon and rejection of linearity in history, it follows logically that the specificity of the phenomenon should be studied instead of the search for universals. As noted, Dilthey adopts the possibility of generating general spiritual phenomena from the singular experiences of individuals through understanding; however, these experiences have a common meaning only within the historical epoch in which they manifest. The historical course is a discontinuous series of unique epochs, the specifics of which cannot be subsumed under general laws: instead of discovering general laws, the social sciences are directed at the study of types, within which the peculiarities of historical 
entities and their parts can be explored. Thus, the aim of the social sciences is to understand social phenomena, to move from individual experiences, to generalize them through objectification, and to interpret their specificities through understanding. According to Roscher, the historian must be an artist in compiling descriptions that faithfully represent historical events, while including only relevant information. To separate the relevant from the irrelevant, the historian uses intuition and the study of law (Agevall 1999, 49-50). Windelband points out that the cases to which we attach value are unique and therefore of interest in social science as opposed to the general elements that have no value aspect (Oakes 1997, 65). Rickert similarly concludes that the scientist must distinguish the essential from the irrelevant in the study of the whole historical course, but considers that the criteria for such a decision are cultural values (Milić 2014, 128-129).

In positivism, understanding is not the discovery of the inner aspect and meaning of phenomena, but the discovery of the internal logic of phenomena in order to master them. Menger defines it as "[...] knowledge that goes beyond immediate experience and then mastering the real world" (Menger 2008, 62). Certain forms of phenomena are repeated throughout history, forming types on the basis of which study can lead to general knowledge, and as a result of understanding, it is possible to master the real world in such a way that the appearance of the studied phenomenon can be induced. Atypical phenomena, unique appearance - does not exist (Menger 2008, 47).

In line with his primary goal of separating the positive spirit of science from metaphysics, Comte emphasizes the importance of discovering the law as a constant relation between phenomena as opposed to a fruitless focus on causes (Fiamengo 1987, 120). This position is understandable in the context of humanistic and practical positive science. Explanation of phenomena is not an end in itself, but serves to improve society: "from science comes prediction; from prediction comes action" (Comte 1989, 49). Thus, the usefulness of positive science versus futility rather refers to the focus of human intelligence on issues unattainable to the human mind in the theological and metaphysical stages, as opposed to drawing attention to specific, solvable scientific problems in the positive phase of science development.

\section{Confronting Absolute Laws with CONTEXtual ANAlysis AND HeRmeneutics}

Comte emphasizes the need to view all phenomena as subordinate to "invariable natural laws whose accurate detection and minimization is the goal of all our efforts" (Comte 1989, 28). Emphasizing the universality of the law does not mean complete separation of the law formulation process from the study of history. Thus, Comte determines the law of the development of society as well as of scientific knowledge (theological, metaphysical and positive stages) in accordance with history, that is, on the basis of historical observations. Of course, despite this assertion, the use of historical observations in the formulation of three stages is debatable, and Comte can be objected to due to analyzing ideas versus facts and a reductionist and utopian linear view of humanity's historical development (Dirkem [Durkheim] 1963, 35). According to Menger (2008), two levels of knowledge can be reached in the theoretical sciences: empirical-realist and exact knowledge. Empirical-realist orientation includes knowledge of real types and exact laws, understood as theoretical knowledge of regularities, which need not be without exception. Exact orientation, on the other hand, seeks to discover the natural laws governing phenomena without exception, relying in part on empirical-realist analysis, but largely through theoretical research. There is no difference 
between the natural and social sciences regarding the possibility of discovery of exact laws, although the element of the voluntary action of subjects must also be taken into account in the social sciences, the logic of the procedure is analogous to that of the natural sciences (Menger 2008, 198). This definition can also be understood as an attempt to highlight two different streams of research, including historical orientation; the aforementioned division was met with sharp criticism from Schmoller, who saw it as reformulated opposition of induction and deduction methods. Historical studies are not excluded from Menger's conception either; they can be classified as empirical-realistic knowledge.

Historists differ on the possibility of discovering certain forms of law in the social sciences: Rickert points out that history is made up of unique events that cannot be covered by law; Dilthey rejects the possibility of forming hypotheses and laws in the studies of the social world, while Roscher, Knies and Schmoller allow the possibility of formulating laws, though not universal ones. Roscher believes that induction can lead to "natural laws" in economics, on the basis of a comparison of the histories of the subject under study, a generalization of common characteristics and descriptions of deviating cases (Agevall 1999, 52). The relativity of the laws is emphasized in this notion: it is important to compare societies that are in the same stage of development, since the economy changes depending on the stage of development of the society and that the rules that apply at one stage are not applicable in lower or higher levels of development. Thus, these laws, though called "natural laws", imply a definition that is fundamentally different from Menger's understanding of the term, which is more about experiential generalizations than laws in the strict sense of the word. Like Roscher, Knies believes that economics is a political science and therefore its conclusions cannot be regarded as universal for all societies: the economic state is the product of the historical development of society and arises from a whole social organism that exists in specific spatial, temporal and national conditions. Knies calls this misconception (from the historian's point of view) the universality of economic laws theoretical absolutism, which encompasses cosmopolitanism (universality of validity for different societies) and perpetualism (universality of validity for different periods of time) (Agevall 1999, 52). Windelband points out that the discovery of the law may explain phenomena in part, emphasizing what is common in phenomena, but historical descriptions should be employed to highlight the specificity of the phenomenon (Milic 2014, 126). The specificity of phenomena can be represented by detailed descriptions and classification of its characteristics; Schmoller believes that the essence of a phenomenon can be obtained by reviewing and synthesizing a description of its various manifestations, rather than by reducing it to general, common characteristics (Bostaph 1978, 10). Descriptive behavior is not the ultimate goal of the social sciences, but detailed descriptions of phenomena, their classification and interpretation of statistical regularities should be the basis for establishing general generalizations and laws in the future of science (Agevall 1999, 63). However, the laws that can be reached in the social sciences are not universal but relative, historical in nature. In addition, there is the need for knowledge accumulation through description, classification and comprehension, before attempting to form a synthesis of scientific knowledge.

The above characteristics of the positivist and historists approach also lead to a different understanding of the significance of the socio-historical context in which the observed phenomena are situated. According to historists, phenomena are part of the physical and spiritual whole of humanity and cannot be viewed outside of this context. Historicism is characterized by "[...] delving into the peculiarities of historical development, the universal spirit of observing history, which solely from the context of 
development seeks to determine the value of a particular factual state, and the historical spirit of the science of society, seeking an explanation and rule of modern life in the study of the past in which it is at last spiritual life at every point in history" (Diltaj 1980, 44, our translation). Every element of scientific thinking must be placed in the context of knowledge of all human nature, formed through experience and study; this principle is emphasized within the framework of hermeneutics as a theory of the method of the spiritual sciences (Brdar 2008, 134). The hermeneutical circle allows for an understanding of meaning within a social context: it is an interpretation of the relationship between the parts and the whole of the objective spirit. Hermeneutics is suitable for the scientific knowledge of great personalities and creators, whose recorded works represent a "permanently fixed expression of life" (Milić 2014, 146, our translation) that enables objective interpretation. Given the notion of the complete discontinuity of history, the requirement to study phenomena in an unrepeatable social and historical context precludes the possibility of discovering universal regularities on which the positivists insist. In fact, Menger points out that the requirement to study context-related phenomena is "at the very least methodological nonsense" (Menger 2008, 81). Different sciences can make it possible to know the totality of reality by consolidating their knowledge when they reach a certain level of development in the future; but by then, Menger believes, scientific inquiry must be approached within the boundaries of a defined subject and discipline. Positivists reject the unification of the phenomenon with the socio-historical context in which it takes place, believing that it is possible to isolate the studied phenomenon by abstraction and focus the study on the elements of the phenomenon itself, in order to discover regularity and law. Observing the phenomenon in a broader context makes it impossible to deal with the phenomenon itself, extending the subject of science to irrelevant aspects and limiting the possibilities of formulating universal regularities. It is precisely because of abstraction of phenomena from the socio-historical context that historists resent positivists, considering that the essence of the phenomenon is elusive without its consideration in the process of historical development of society.

\section{STRUCTURE OF THE SCIENCE SYSTEM AND THE POSSIBILITIES OF KNOWLEDGE SYNTHESIS}

Although, looking at the method and scope of social science knowledge from different aspects, the authors of both directions believe that the combined results and discoveries of different sciences will lead to the realization of social reality as a whole. There are different ways of realizing the unification of the knowledge of different sciences. According to Dilthey, such knowledge will unify universal history and "the system of self-constituted sciences of man, language, economy, state, law, religion, and art are complementary" (Diltaj 1980, 190, our translation), while Comte believes that the pinnacle of the positive philosophies is to be realized in the system of natural and social sciences consisting of astronomy, physics, chemistry, physiology and sociology. Comte's system of sciences is governed by the principle of increasing complexity and diminishing generality. The natural and social sciences form a unique system of sciences, which studies reality in totality; thus sociology is the last element of the system of sciences leading to the ultimate victory of positive philosophy. Menger believes that the development of all exact social sciences will enable examination of the social world as a whole, analogous to that of the natural sciences, albeit in the distant future (Menger 2008, 80). An exception to viewing social science subject as fundamentally different from natural science subject are Windelband and Rickert, 
who believe that differences in the natural and social science method stem from different cognitive goals. Windelband points out that scientific knowledge can be directed toward the discovery of the universal, in the form of the laws of nature or the particular, or in the form of historical structures; one may strive to discover what is general and common to phenomena or what is specific about a concrete, real phenomenon. Therefore, the sciences can also be divided into two groups: event science (Ereigniswissenchaften) and law science (Geisteswissenchaften). This division does not correspond to the division into natural and social sciences, since these groups of sciences may apply a nomothetic or idiographic approach depending on their goals (Brdar 2008, 135). Dilthey states that both the natural and social sciences examine objects on the basis of facts, with the difference in the tendency of object formation: "In some (spiritual sciences) one spiritual object is formed in understanding, and in other (natural sciences) physical object is formed in knowledge" (Diltaj 1980, 126, our translation). The natural sciences explain the physical world but do not allow understanding. Knies distinguishes three groups of sciences: those that study natural phenomena, sciences that study spiritual, intangible phenomena, and historical sciences that encompass both types of phenomena. Historical sciences study primarily "human actions, conditions, and tasks oriented toward the accomplishment of human purpose" (as cited in Agevall 1999, 55-56) and then inanimate, material objects to the extent that they are relevant to human action.

The perceptions of the cognitive possibilities of the social sciences in relation to the natural sciences are differently viewed in these directions: the methodological monism of the positivists leads to the observation of the natural and social sciences within a single system of science, while historists emphasize the specificity and isolation of the social sciences. Historists seek to achieve the autonomy of the social sciences through an appreciation of their specificity arising from the subject of study, which entails the most complex and least predictable part of reality. Their goal is also to understand the whole world of life, but the gains of comprehending that world are not seen as the pinnacle of a unified scientific system of natural and social sciences, but viewed as a dive into the depths of the inner world of social phenomena. From this perspective, the historical concept of the social sciences allows for greater depth of knowledge, in terms of the study of categories of the spiritual world that positivism explicitly rejects as metaphysical speculation and the realization that it is possible to obtain general knowledge on the basis of the singular. Also, both directions seek to affirm the social sciences, with positivists trying to emphasize their objectivity and precision, equating them with the natural sciences, while historists separate social sciences from the natural sciences, insisting on their independence based on the specificity of the subject of study, which includes phenomena and categories inaccessible natural sciences.

\section{CONCLUSION}

Within the dispute over method, significant methodological questions have been raised that point to the possibilities and limits of the social sciences. Different views of the knowledge capacities of the social sciences in opposing directions stem primarily from different conceptions of its subject. As we pointed out, in striving to delimit scientific knowledge and metaphysics, positivists limit the subject of social science to available empirical, observable, and sensible facts, negating the intrinsic properties of social life. 
Historists insist on these properties, believing that the specificity of the subject is embodied in internal spiritual categories that can be manifested through comprehension, interpretation of experience and objectification. Given these starting concepts, the scientific goals of the social sciences differ. Positivists emphasize the need for explanation, and historists the need for understanding social phenomena; according to the former, the goal of science is to arrive at universal laws, while only some historists allow the possibility of discovering empirical generalizations, after detailed descriptions and classification of extensive experiential material. Thus, what also arises from different approaches to the subject is the focus on different goals, comprehension versus explanation, induction versus deduction, and laws versus generalizations and case studies. Defined goals of social science are also influenced by the notion of the character of history. While according to positivism science should be interested in universal elements in phenomena, historism emphasizes the importance of individual, unique phenomena, considering history as a series of unrepeatable events. From such a discontinuity of phenomena, scholars choose significant objects of study on the basis of cultural values. Social phenomena should be, therefore, studied in the context of history and society. Thus, the rejection of universal laws and abstract generalizations in historism stems from the specific approach to the history and humanity itself, not from the limitations or weaknesses of social science. As Dilthey points out, in the social sciences, life studies life; the social sciences are not at a disadvantage compared to the natural sciences, instead they are at an advantage because they allow understanding of the subject. Both directions advocate the independence of the social sciences, and do not show a tendency to limit the cognitive possibilities of the social sciences, but in different ways look at the direction of the possible development of the social sciences - towards the conquest of the external or internal world.

\section{REFERENCES}

Agevall, Ola. A Science of Unique Events: Max Weber's Methodology of the Cultural Sciences, PhD diss., Uppsala University, 1999.

Bostaph, Samuel. „The Methodological Debate between Carl Menger and the German Historists”. Atlantic Economic Journal 6, 3 (1978): 3-16.

Brdar, Milan. Pouke skromnosti: Karl Poper, otvoreno društvo, nauka i filozofija. Beograd: Zavod za udžbenike, 2008.

Comte, August. Kurs pozitivne filozofije. Nikšić: Univerzitetska riječ, 1989.

Diltaj, Vilhelm. Uvod u zasnivanje duhovnih nauka. Beograd: Prosveta, 1980

Dirkem, E. Pravila sociološkog metoda. Beograd: Savremena škola, 1963.

Fiamengo, Ante. Saint-Simon i Auguste Comte. Zagreb: Naprijed, 1987.

Kolakovski, Lešek. Filozofija pozitivizma. Beograd: Prosveta, 1972.

Oakes, Guy. "Value Theory and the Foundations of the Cultural Sciences: Remarks on Rickert." In Methodology of the social sciences, ethics, and economics in the newer historical school: from Max Weber and Rickert to Sombart and Rothacker, edited by Peter Koslowski, 59- 78. Boston: Springer, 1997.

Menger, Karl. Istraživanja o metodi društvenih nauka, s posebnim osvrtom na političku ekonomiju. Beograd: Službeni glasnik, 2008.

Milić, Vojin. Sociološki metod. Beograd: Nolit, 2014.

Stojanović, Božo. "Karl Menger i austrijska škola." U Istraživanja o metodi društvenih nauka, s posebnim osvrtom na političku ekonomiju, 1-25. Beograd: Službeni glasnik, 2008.

Shionoya, Yuichi. The Soul of the German Historical School: Methodological Essays on Schmoller, Weber and Schumpeter. Boston: Springer Science, Business Media, Inc, 2005.

Turner, Jonathan. H. "Explaining the Social World: Historism versus Positivism". The Sociological Quarterly 47 (2006): $451-463$ 


\section{PRILOG TUMAČENJU SPORA OKO METODA U DRUŠTVENIM NAUKAMA}

U radu su analizirane osnovne teorijske postavke učesnika spora oko metoda (Methodenstreit). Suprotstavljena gledišta pozitivista i istorista su analizirana prema ključnim pozitivističkim regulama koje izdvaja Kolakovski (1972): fenomenalizam, nominalizam, osporavanje saznajne vrednosti vrednosnih sudova $i$ jedinstvo naučnog metoda. Posebno su razmotrene glavne posledice različitih shvatanja odnosa metoda prirodnih $i$ društvenih nauka: a) shvatanje cilja društvenih nauka: razumevanje i objašnjenje, b) mogućnosti otkrića univerzalnih zakona nasuprot kontekstualnoj analizi jedinstvenih pojava; c) mesto društvenih nauka u sistemu nauka. Ukazano je na nastojanja predstavnika oba pravaca ka afirmaciji saznajnih mogućnosti društvenih nauka, ali uz različitu percepciju pravca razvoja društvenih nauka - ka osvajanju spoljašnjeg ili unutrašnjeg sveta.

Ključne reči: Methodenstreit, pozitivizam, istorizam, metod društvenih nauka. 